\title{
Production and Quality Evaluation of Functional Biscuits from Whole Wheat Flour Supplemented with Acha (Fonio) and Kidney Bean Flours
}

\author{
Ufot E. Inyang*, Etini A. Daniel and Florence A. Bello \\ Department of Food Science and Technology \\ University of Uyo \\ Uyo Akwa Ibom State, Nigeria \\ ${ }^{*}$ Corresponding author's email: inyang.ufot [AT] yahoo.com
}

\begin{abstract}
Composite flours are used for bakery products to improve the nutritional value and reduce the reliance on wheat importation. The present study was aimed at assessing the effect of supplementing whole wheat flour with acha and red kidney bean flours on the physical properties, proximate composition, mineral and sensory characteristics of biscuits made from the blends. Blend ratios used were 100:00:00 ( $T_{1}$, control sample), 75:25:00 $\left(T_{2}\right)$, 75:00:25 $\left(T_{3}\right)$ and 50:25:25 $\left(T_{4}\right)$ (whole wheat: acha: kidney bean flour). The result showed that all the parameters varied with the composition of flours in the blends. The biscuit weight, diameter, thickness and spread ratio ranged from 16.32 to $19.08 \mathrm{~g}, 4.02$ to $4.40 \mathrm{~cm}, 0.69$ to $0.78 \mathrm{~cm}$ and 5.33 to 6.38 respectively. Incorporation of kidney bean flour in the blends led to the reduction in spread ratio of the biscuit. The protein, fat, ash, crude fibre and carbohydrate contents in the biscuits ranged from 11.73 to $15.20 \%$, 16.34 to $17.95 \%, 1.52 \%$, to $1.73 \%, 1.65$ to $1.80 \%$ and 63.36 to $68.70 \%$ respectively. Samples $T_{3}$ and $T_{4}$ with kidney bean flour incorporation had higher protein, dietary fibre and lower carbohydrate contents than samples $T_{1}$ and $T_{2}$ with no kidney bean flour incorporation. The calcium, potassium, magnesium, iron and zinc contents ranged from $36.14-45.72 \mathrm{mg} / 100 \mathrm{~g}, 105.40-128.72 \mathrm{mg} / 100 \mathrm{~g}, 29.60-46.81 \mathrm{mg} / 100 \mathrm{~g}, 3.89-$ $5.12 \mathrm{mg} / 100 \mathrm{~g}$ and $2.01-3.51 \mathrm{mg} / 100 \mathrm{~g}$ respectively. Incorporation of kidney bean flour enhanced the calcium, magnesium and iron contents in the biscuits. Sensory mean score values showed that samples $T_{3}$ and $T_{4}$ were the most preferred samples in terms of overall acceptability as their values were not significantly $(p>0.05)$ difference from each other. It is evident from the study that acceptable biscuits of improved nutritional value and high dietary fibre content could be produced from whole wheat flour supplemented with acha and kidney beans flours. This will increase the utilization of these locally grown crops and reduce wheat importation into the country. The high fibre biscuit will also possess several health benefits.
\end{abstract}

Keywords--- Biscuits, whole wheat flour, acha flour, kidney bean flour, nutritional composition, sensory characteristics

\section{INTRODUCTION}

Biscuits are one of the popular wheat based snack foods consumed by a wide range of population in Nigeria, especially school children due to their affordability, convenience, shelf stable and nutritive value. Since biscuits are widely accepted and consumed by almost all profile of consumers from many countries, they therefore offer a valuable supplementation vehicle for nutritional improvement. The local production of wheat (major raw material for biscuit making) in Nigeria is far below domestic consumption due to unfavourable climatic conditions. Consequently, Nigeria like other tropical countries is still depending on wheat importation to augment local production and this places a considerable burden on the economy of the country. Compositing wheat flour with flours from locally available cereals, roots and legume crops has been encouraged since it reduces wheat importation [1].

The popularity of wheat grain for the production of confectionery products is because of the unique properties of its protein (gluten) which combines strength and elasticity to baked products including biscuit. Whole wheat is a concentrated source of essential nutritional components including minerals, vitamins, protein, fat and fibre while the refine flour is mostly starch [2]. Baked products made from whole meal wheat flour therefore contain higher minerals, vitamins and dietary fibre contents than products from white wheat flour [3]. Wheat also possesses several health benefits, especially when utilized as a whole grain product. Whole wheat products have been reported to provide protection against diseases such as constipation, ishaemia, heart disease, diverticulum, appendicitis, diabetes and obesity [4]. These benefits are attributed in part to the presence of different compounds such as dietary fibres, phytochemicals, protein, vitamins and minerals [5].

Acha (Digitaris exilis), also called fonio or "hungry rice" is an annual crop indigenous to West Africa where it is cultivated for its straw and edible grains [6]. It belongs to the Poaceae family. It is widely cultivated and consumed in the 
Northern part of Nigeria. Acha has tiny grains and is consumed whole or milled into flour and can be processed into a variety of preparations such as gruel, porridges, alcoholic and non-alcoholic beverages [7]. The proximate analysis of the grain revealed that it contains $7.9 \%$ protein, $1.8 \%$ fat, $71 \%$ carbohydrate and $6.8 \%$ fibre [8]. The protein content is high in methionine and cysteine which are vital for human health and lacking in most cereals [9, 10]. It is higher in calcium, magnesium, iron and copper but lower in potassium, sodium, lead and manganese than most cereals [11]. Consumption of acha as whole grain makes it an excellent source of dietary fibre which is good for individuals suffering from obesity and diabetes. Ibrahim and Saidu [12] reported that undehulled acha has the ability to control blood sugar level and can be recommended to individuals suffering with diabetes. In spite of its nutritional and health benefits, acha remains one of the neglected and underutilized grains in Nigeria.

Kidney bean (Phaseolus vulgaris) is one of the most widely cultivated and consumer food legumes and is a vital source of protein $(22.7 \%)$, B-vitamins and minerals [13]. It is one of the tropical legumes that can be used to enhance the protein content in the diet of low and medium income earners who cannot afford protein from conventional animal source because of their high prices in Nigeria. The presence of complex carbohydrate and dietary fibre in kidney beans contribute to its low glycemic index, which has been proved to be associated to reduce the risk of heart disease, diabetes and obesity [14]. Red kidney beans have low sodium content and saturated fatty acid but are rich in unsaturated fatty acids especially linoleic acid [15]. In spite of its high nutritive and health benefits, raw kidney beans contain large amount of anti-nutritional factors including phytic acid, hemagglutinins, trypsin inhibitors, tannins and saponin which can affect the absorption of protein and certain minerals [16]. Traditional processing methods such as soaking, boiling, germination and fermentation have been proven to be effective in reducing or eliminating anti-nutritional factors present in legumes [17, 18].

Wheat and acha flours are high in carbohydrate but low in protein content. Blending of cereal flour with legume flour such as kidney bean flour with high protein content would help to improve the nutritional value of the product and could be used to alleviate the problem of protein energy malnutrition still prevalent in our communities. The aim of the present study was to evaluate the physical properties, nutritional composition and sensory characteristics of biscuits produced from whole wheat flour supplemented with acha and kidney bean flours.

\subsection{Materials Procurement}

\section{MATERIALS AND METHODS}

Whole wheat grains and kidney beans were purchased from Itam market in Uyo metropolis of Akwa Ibom State, while acha grains were purchased from a local market in Jos, Plateau State, Nigeria. Ingredients used for biscuit making (butter, egg, sugar, baking powder, sodium bicarbonate and vanilla) were purchased from a supermarket in Uyo, Akwa Ibom State, Nigeria.

\subsection{Preparation of Materials \\ 2.2.1 Preparation of Wheat Flour}

The whole wheat grains were processed into flour following the method described by Ndife et al. [19]. The grains were cleaned from dirt by sorting out contaminants such as sticks, leaves and sand, washed in potable water and dried at $55^{\circ} \mathrm{C}$ in a conventional air oven (model pp, $22 \mathrm{US}$, Genlab, England). The grains were then milled in attrition mill, sieved to pass through $425 \mu \mathrm{m}$ aperture screen, packaged in an air tight container, labeled and stored at $4^{\circ} \mathrm{C}$ for subsequent use.

\subsubsection{Preparation of Acha Flour}

Acha flour was prepared following the method described by Olapade and Aworh [20]. The grains were cleaned by manually removing extraneous materials like chaff, stone and stalks. This was followed by washing in potable water and stones removed by sedimentation. The washed grains were dried in an oven at $55^{\circ} \mathrm{C}$, milled using attrition mill, sieved through $425 \mu \mathrm{m}$ mesh screen, packaged in an air tight container, labeled and stored at $4^{\circ} \mathrm{C}$ for subsequent use.

\subsubsection{Preparation of Kidney Bean Flour}

The method described by Chaudhary and Sharma [21] was followed in the preparation of red kidney bean flour. The beans were thoroughly cleaned, blanched in hot water $(1: 5 \mathrm{w} / \mathrm{v})$ at $100^{\circ} \mathrm{C}$ for $30 \mathrm{~min}$, drained, washed with fresh water and soaked overnight at room temperature $\left(27 \pm 2^{\circ} \mathrm{C}\right)$. The soaked water was drained off, beans were manually dehulled and dried in a conventional oven (model pp, $22 \mathrm{US}$, Genlab, England) at $55^{\circ} \mathrm{C}$. The dried beans were milled, sieved to pass through $425 \mu \mathrm{m}$ mesh screen, packaged in an air tight container, labeled and stored at $4^{\circ} \mathrm{C}$ for subsequent use.

\subsubsection{Supplementation of Whole Wheat Flour with Acha and Kidney Bean Flours.}

The blending ratios used for the present study are as shown in Table 1 . The $100 \%$ whole wheat flour $\left(\mathrm{T}_{1}\right)$ served as the control sample. 
Table 1: $\quad$ Blending ratio of whole wheat, acha and kidney bean flours

\begin{tabular}{cccc}
\hline Sample Codes & Whole Wheat Flour & Acha Flour & Kidney Bean Flour \\
\hline $\mathrm{T}_{1}$ & 100.00 & 00.00 & 00.00 \\
$\mathrm{~T}_{2}$ & 75.00 & 25.00 & 00.00 \\
$\mathrm{~T}_{3}$ & 75.00 & 00.00 & 25.00 \\
$\mathrm{~T}_{4}$ & 50.00 & 25.00 & 25.00 \\
\hline
\end{tabular}

\subsubsection{Ingredients Formulation for Biscuit Production}

The formulation used by Man et al. [22] as shown in Table 2 was followed in the preparation of the biscuits.

Table 2: Ingredient formulation (g) for biscuit production

\begin{tabular}{lcccc}
\hline Parameters & $\mathbf{T}_{\mathbf{1}}$ & $\mathbf{T}_{\mathbf{2}}$ & $\mathbf{T}_{\mathbf{3}}$ & $\mathbf{T}_{\mathbf{4}}$ \\
\hline Flour & 100 & 100 & 100 & 100 \\
Butter & 20 & 20 & 20 & 20 \\
Sugar & 17 & 17 & 17 & 17 \\
Egg & 40 & 40 & 40 & 40 \\
Sodium bicarbonate & 8 & 8 & 8 & 8 \\
Honey & 27 & 27 & 27 & 27 \\
Vanilla essence & 9 & 9 & 9 & 9 \\
\hline
\end{tabular}

\subsubsection{Preparation of Biscuits}

The biscuits were produced following the creamy method described by Man et al. [22]. The butter, honey and granulated sugar were creamed together until light and fluffy. Flour, sodium bicarbonate, egg and vanilla essence were added to the cream and mixed in a bowel mixer to form dough. The dough was rolled to a uniform thickness, cut to a uniform diameter and baked in an oven at $180^{\circ} \mathrm{C}$ for 15 minutes, cooled at ambient temperature $\left(27^{\circ} \mathrm{C}\right)$, packaged in high density polyethylene, labeled and stored at ambient temperature for various determinations.

\subsection{Methods of Analysis}

\subsubsection{Determination of Physical Characteristics}

Weight of the biscuit was measured using a digital weighing balance and mean values of five individual biscuits recorded. The biscuit diameter was determined by placing six biscuits horizontally (edge to edge) in a row and the diameter was measured with a digital vernier caliper with $0.01 \mathrm{~mm}$ accuracy [22]. The mean value was recorded as the diameter of the biscuits. Thickness of biscuit was determined by stacking six biscuits, one on top of another and the average thickness was taken using digital vernier caliper with $0.01 \mathrm{~mm}$ accuracy [22]. The mean value was recorded as the thickness of the biscuit. The spread ratio was calculated as the average diameter/thickness [23].

\subsubsection{Determination of Nutrient Composition of biscuits:}

Moisture, crude protein, fat, ash and crude fibre were determined by the methods described in AOAC [24]. Carbohydrate content was calculated by difference [25]. Energy value was calculated using Atwater factor formula [26]. Mineral content ( $\mathrm{Ca}, \mathrm{K}, \mathrm{Mg}, \mathrm{Fe}$ and $\mathrm{Zn}$ ) were determine using atomic absorption spectrophotometer (UNICAM Model 939, UK) as described in AOAC [24].

\subsubsection{Sensory Evaluation}

The sensory evaluation of the biscuits was performed by 20 semi-trained pannel of judges drawn from the University Community, University of Uyo, Uyo, Nigeria. All panelists were regular consumers of biscuits and were familiar with sensory quality attributes of biscuits. The evaluation was conducted using the nine-point hedonic scale ranging from 1 (disliked extremely) to 9 (liked extremely) [27]. The samples were coded with three digit random numbers and presented in identical containers. Questionnaire for entering scores and potable water for mouth rinsing between tasting were made available to the panelists. Each sample was rated for appearance, taste, texture, crispiness and overall acceptability.

\subsection{Statistical Analysis}

Triplicate data were subjected to a one-way analysis of variance (ANOVA) using SPSS statistical package version 18 (SPSS, Inc, Chicago, USA). Significant differences between means were determined with Duncan's Multiple Range Test (DMRT) at $\mathrm{p}<0.05$. 


\subsection{Physical Characteristics of Biscuits}

\section{RESULTS AND DISCUSSION}

The mean values of physical characteristics of $100 \%$ whole wheat biscuit (control) and biscuits from composite flours are presented in Table 3. The result showed that all the characteristics determined varied with the composition of different flours in the blends. The weight of the biscuits ranged from 16.32 to $19.08 \mathrm{~g}$ with sample $\mathrm{T}_{2}$ as the heaviest biscuit while sample $\mathrm{T}_{3}$ had the least weight. Addition of acha flour caused significant $(\mathrm{p}<0.05)$ increase in the weight of the biscuit while incorporation of kidney bean flour caused significant $(\mathrm{p}<0.05)$ reduction in the weight of biscuits. This observation is in agreement with the report by Thongram et al. [28] who recorded reduction in the weight of cookies as a result of supplementation of wheat flour with legume flours. Variation in the weight of biscuits could be attributed to differences in the water holding capacity of the flours used [28].

Table 3: $\quad$ Physical properties of biscuits made from whole wheat flour supplemented with acha and kidney bean flours

\begin{tabular}{lcccc}
\hline \multirow{2}{*}{ Parameters } & \multicolumn{4}{c}{ Sample Codes } \\
\cline { 2 - 5 } \multicolumn{1}{c}{$\mathbf{T}_{\mathbf{1}}$} & $\mathbf{T}_{\mathbf{2}}$ & $\mathbf{T}_{\mathbf{3}}$ & $\mathbf{T}_{\mathbf{4}}$ \\
\hline Weight $(\mathrm{g})$ & $17.63 \pm 0.02$ & $19.08 \pm 0.05$ & $16.32 \pm 0.02$ & $16.94 \pm 0.08$ \\
Diameter $(\mathrm{cm})$ & $4.38 \pm 0.06$ & $4.40 \pm 0.04$ & $4.16 \pm 0.11$ & $4.02 \pm 0.03$ \\
Thickness $(\mathrm{cm})$ & $0.71 \pm 0.04$ & $0.69 \pm 0.10$ & $0.78 \pm 0.06$ & $0.74 \pm 0.05$ \\
Spread Ratio & $6.17 \pm 0.03$ & $6.38 \pm 0.02$ & $5.33 \pm 0.05$ & $5.43 \pm 0.04$ \\
\hline
\end{tabular}

Values are means \pm SD (standard deviation) of triplicate determinations. Means on the same row with different superscripts are significantly different at $\mathrm{p}<0.05$. $\mathrm{T}_{1}=100 \%$ whole wheat flour biscuit; $\mathrm{T}_{2}=75 \%$ whole wheat, $25 \%$ acha and $0 \%$ kidney bean flours blend biscuit; $\mathrm{T}_{3}=75 \%$ whole wheat, $0 \%$ acha, and $25 \%$ kidney beans flours blend biscuit; $\mathrm{T}_{4}=50 \%$ whole wheat, $25 \%$ acha and $25 \%$ kidney bean flours blend biscuit.

The diameter and thickness of the biscuits ranged from $4.02-4.40 \mathrm{~cm}$ and $0.69-0.78 \mathrm{~cm}$ respectively. Biscuits from the blends that contained kidney bean flour $\left(\mathrm{T}_{3}\right.$ and $\left.\mathrm{T}_{4}\right)$ exhibited significantly $(\mathrm{p}<0.05)$ lower diameter but higher thickness than the control biscuit $\left(\mathrm{T}_{1}\right)$ and biscuit from the composite of $75 \%$ wheat and $25 \%$ acha flours [ $\mathrm{T}_{2}$ ]. The maximum diameter was observed in sample $\mathrm{T}_{2}(4.40 \mathrm{~cm})$ and minimum in sample $\mathrm{T}_{4}(4.02 \mathrm{~cm})$. The maximum thickness was observed in sample $T_{3}(0.78 \mathrm{~cm})$ and minimum in sample $T_{2}(0.69 \mathrm{~cm})$. These variations in biscuit diameter and thickness were reflected in the spread ratio which was calculated by dividing diameter by thickness of the biscuits. Spread ratio has long been used as an important characteristic for determining the quality of flour for cookies/biscuit production [29]. Biscuits with higher spread ratio values are considered to be more desirable than those with lower values [30, 31]. In the present study, sample $\mathrm{T}_{3}$ exhibited the least spread ratio (5.33) while sample $\mathrm{T}_{2}$ had the highest spread ratio (6.38). Other researchers $[28,30,32,33]$ also reported that biscuits/cookies from blends with legume seed flour incorporation had lower spread ratio than those from $100 \%$ wheat flour. The decrease in spread ratio of kidney bean flour supplemented biscuits might be due to the availability of more hydrophilic sites that compete for limited free water in the biscuit dough due to high protein content in the flour [34]. According to Zucco et al. [31] and Tiwari et al. [32], for the blend containing legume flour, the increasing number of hydrophilic sites available due to increased protein content competes for the limited free water in the dough thereby affecting the spread ratio.

\subsection{Proximate Composition of Produced Biscuits}

The proximate composition of the prepared biscuits is presented in Table 4. The result showed that the proximate composition of the biscuits varied with the composition of flours in the blends. The protein and carbohydrate contents in the biscuits ranged from 11.73 to $15.20 \%$ and 63.36 to $68.70 \%$ respectively. Sample $\mathrm{T}_{3}$ had the highest protein (15.20\%) and lowest carbohydrate contents $(63.36 \%)$ while sample $\mathrm{T}_{2}$ had the least protein content $(11.73 \%)$ and highest carbohydrate content $(68.70 \%)$. Incorporation of kidney bean flour in the blends caused significant $(p<0.05)$ increase in the protein content in the biscuits. This could be attributed to higher amount of protein content in kidney bean flour relative to the other two flours. Kidney bean has been reported to contain $25.78 \%$ protein [35] relative to $13.07 \%$ reported for whole wheat flour [36] and $7.90 \%$ reported for acha flour [8]. According to Tharanathan and Mahadevamma [37], legumes generally contain more protein than cereals. The observed higher protein and lower carbohydrate contents in kidney bean flour supplemented biscuits $\left(\mathrm{T}_{3}\right.$ and $\left.\mathrm{T}_{4}\right)$ relative to the biscuits from blends with no kidney bean flour incorporation ( $\mathrm{T}_{1}$ and $\mathrm{T}_{2}$ ) are in agreement with the reports from other researchers [28, 33, 36]. The result suggests that whole wheat biscuits supplemented with red kidney bean flour may be useful as food supplement for the alleviation of protein malnutrition in vulnerable group. 
Table 4: $\quad$ Proximate composition of biscuits made from whole wheat flour supplemented with acha and kidney bean flours (dry matter basis)

\begin{tabular}{lcccc}
\hline \multirow{2}{*}{\multicolumn{1}{c}{ Parameters }} & \multicolumn{4}{c}{ Sample Codes } \\
\cline { 2 - 5 } \multicolumn{1}{c}{$\mathbf{T}_{\mathbf{1}}$} & \multicolumn{1}{c}{$\mathbf{T}_{\mathbf{2}}$} & $\mathbf{T}_{\mathbf{3}}$ & $\mathbf{T}_{\mathbf{4}}$ \\
\hline Crude Protein (\%) & $12.05^{\mathrm{c}} \pm 0.03$ & $11.73^{\mathrm{d}} \pm 0.05$ & $15.20^{\mathrm{a}} \pm 0.02$ & $14.93^{\mathrm{b}} \pm 0.08$ \\
Crude fat $(\%)$ & $16.82^{\mathrm{c}} \pm 0.011$ & $16.34^{\mathrm{c}} \pm 0.09$ & $1.95^{\mathrm{a}} \pm 0.00$ & $17.41^{\mathrm{b}} \pm 0.04$ \\
Ash $(\%)$ & $1.58^{\mathrm{c}} \pm 0.07$ & $1.52^{\mathrm{c}} \pm 0.02$ & $1.69^{\mathrm{b}} \pm 0.04$ & $1.73^{\mathrm{a}} \pm 0.02$ \\
Crude fibre (\%) & $1.65^{\mathrm{c}} \pm 0.15$ & $1.71^{\mathrm{b}} \pm 0.08$ & $1.80^{\mathrm{a}} \pm 0.20$ & $1.76^{\mathrm{b}} \pm 0.14$ \\
Carbohydrate (\%) & $67.90^{\mathrm{a}} \pm 0.06$ & $68.70^{\mathrm{a}} \pm 0.10$ & $63.36^{\mathrm{b}} \pm 0.05$ & $64.17^{\mathrm{b}} \pm 0.03$ \\
Caloric value (kcal/100g) & $471.18^{\mathrm{a}} \pm 0.12$ & $468.78^{\mathrm{b}} \pm 0.07$ & $475.79^{\mathrm{a}} \pm 0.14$ & $473.09^{\mathrm{a}} \pm 0.11$ \\
\hline
\end{tabular}

Values are means \pm SD (standard deviation) of triplicate determinations. Means on the same row with different superscripts are significantly different at $\mathrm{p}<0.05 . \mathrm{T}_{1}=100 \%$ whole wheat flour biscuit; $\mathrm{T}_{2}=75 \%$ whole wheat, $25 \%$ acha and $0 \%$ kidney bean flours blend biscuit; $\mathrm{T}_{3}=75 \%$ whole wheat, $0 \%$ acha, and $25 \%$ kidney beans flours blend biscuit; $\mathrm{T}_{4}=50 \%$ whole wheat, $25 \%$ acha and $25 \%$ kidney bean flours blend biscuit.

The fat content in the biscuits ranged from 16.34 to $17.95 \%$. Sample $\mathrm{T}_{3}$ had the highest fat content (17.95\%) while sample $\mathrm{T}_{2}$ had the lowest fat content $(16.34 \%)$. The fat content in the control sample was $16.82 \%$. Biscuits from the blends that contained kidney bean flour $\left(\mathrm{T}_{3}\right.$ and $\left.\mathrm{T}_{4}\right)$ had significantly $(\mathrm{p}<0.05)$ higher fat content than the control sample $\left(\mathrm{T}_{1}\right)$. Igbabul et al. [38] had similarly reported that cookies from composite of wheat, cocoyam and African yam bean had higher fat content than $100 \%$ wheat cookies. Fat is a rich source of energy and also serves as carriers of fat soluble vitamins A, D, $\mathrm{E}$ and $\mathrm{K}$ [39]. It also serves as a lubricating agent that improves the mouth feel, flavour and palatability of foods [39]. However, high level of fat in food products could lead to rancidity and development of unpleasant odour/flavour.

The ash content of the biscuit ranged from 1.52 to $1.73 \%$. Sample $\mathrm{T}_{2}$ had the lowest ash content (1.52\%) while sample $\mathrm{T}_{4}$ recorded the highest ash content $(1.73 \%)$. The value for the control sample was $1.58 \%$ which was higher than $0.64 \%$ reported by Awan et al. [36] for whole wheat biscuits but lower than $1.63 \%$ and $2.31 \%$ reported by Peter et al. [40] and Ajibola et al. [41] for whole wheat cookies and biscuits respectively. The ash content of a food sample is an index of the mineral element of such food. It is evident from the result that biscuit produced from composite of whole wheat, acha and kidney bean flours blend $\left(\mathrm{T}_{4}\right)$ would provide more mineral elements to the consumers than the rest of the biscuits.

The crude fibre content in the biscuits ranged from 1.65 to $1.80 \%$. The control sample $\left(\mathrm{T}_{1}\right)$ had the least crude fibre value $(1.65 \%)$ while sample $\mathrm{T}_{3}$ had the highest value $(1.80 \%)$. The crude fibre content of the $100 \%$ whole wheat biscuit $(1.65 \%)$ was higher than $1.59 \%$ reported for whole wheat cookies [40] but lower than $2.45 \%$ reported by Ajibola et $a l$. [41] for whole wheat biscuit. The crude fibre values of the composite biscuits were significantly $(\mathrm{p}<0.05)$ different from that of the control sample. Dietary fibre has been shown to have a great impact on the health of the consumers. The presence of high dietary fibre in food products is essential owing to its ability to facilitate bowel movement (peristalsis), bulk addition to food and prevention of constipation [42]. Also, the risk of mortality and morbidity from cardiovascular disease, stroke, diverticulitis, colon cancer and diabetes is reduced when high fibre diet is consumed [43, 44].

Biscuits are energy giving foods that are consumed mostly in-between meals. The caloric value of the prepared biscuits ranged from 468.78 to $475.79 \mathrm{kcal} / 100 \mathrm{~g}$. The protein, fat and carbohydrate constituents contributed to the energy value of the biscuits with fat as the major contributor $(9 \mathrm{kcal} / \mathrm{g})$ while protein and most carbohydrate have about $4 \mathrm{kcal} / \mathrm{g}$. Hence, in this study, sample $\mathrm{T}_{3}$ with the highest fat value also recorded the highest energy value while the least energy value was for sample $T_{2}$ with the least fat content. Similar observation was reported by Farzana and Mohajan [45].

\subsection{Mineral Content in the Biscuits}

The mineral content of the prepared biscuits is presented in Table 5. The result showed that the quantity of mineral element (Ca, K, Mg, Fe and $\mathrm{Zn}$ ) in the biscuits varied with the composition of flours in the blends used for their production. This could be attributed to the variation in these mineral elements in the different flours used in the composite flour formulation. Potassium was the most abundant mineral elements in all the biscuits and was followed by calcium and magnesium while zinc was the least in value. Potassium content in the biscuits ranged from 105.40 to $128.72 \mathrm{mg} / 100 \mathrm{~g}$. Sample $\mathrm{T}_{3}$ had the least value while the highest value was for sample $\mathrm{T}_{1}$. The potassium values were significantly $(\mathrm{p}<0.05)$ different from each other. Potassium intake is required in relatively large amount in the body because it functions as an important electrolyte in the nervous system and has also been shown to exert a powerful, dose-dependent inhibitory effect on sodium sensitivity [46]. Liu et al. [47] reported that increasing the potassium intake of hypertensive rats that were fed high sodium diets lowered blood pressure, reduced incidence of stroke and stroke related death, and prevented cardiac hypertrophy, mesenteric vascular damage and renal injury. 
Table 5: $\quad$ Mineral content of biscuits made from whole wheat flour supplemented with acha and kidney bean flour (mg/100g)

\begin{tabular}{lcccc}
\hline \multirow{2}{*}{ Parameters } & \multicolumn{4}{c}{ Sample Codes } \\
\cline { 2 - 5 } & $\mathbf{T}_{\mathbf{1}}$ & $\mathbf{T}_{\mathbf{2}}$ & $\mathbf{T}_{\mathbf{3}}$ & $\mathbf{T}_{\mathbf{4}}$ \\
\hline Calcium & $36.14^{\mathrm{d}} \pm 0.11$ & $40.38^{\mathrm{c}} \pm 0.02$ & $43.09^{\mathrm{b}} \pm 0.06$ & $45.72^{\mathrm{a}} \pm 0.05$ \\
Potassium & $128.72^{\mathrm{a}} \pm 0.05$ & $116.06^{\mathrm{c}} \pm 0.08$ & $105.40^{\mathrm{d}} \pm 0.10$ & $120.68^{\mathrm{b}} \pm 0.10$ \\
Magnesium & $29.60^{\mathrm{d}} \pm 0.10$ & $35.40^{\mathrm{c}} \pm 0.05$ & $46.81^{\mathrm{a}} \pm 0.08$ & $41.30^{\mathrm{b}} \pm 0.02$ \\
Iron & $4.07^{\mathrm{c}} \pm 0.09$ & $3.89^{\mathrm{d}} \pm 0.03$ & $5.12^{\mathrm{a}} \pm 0.03$ & $4.91^{\mathrm{b}} \pm 0.04$ \\
Zinc & $3.51^{\mathrm{a}} \pm 0.06$ & $2.01^{\mathrm{c}} \pm 0.04$ & $2.15^{\mathrm{c}} \pm 0.05$ & $2.89^{\mathrm{b}} \pm 0.11$ \\
\hline
\end{tabular}

Values are means \pm SD (standard deviation) of triplicate determinations. Means on the same row with different superscripts are significantly different at $\mathrm{p}<0.05$. $\mathrm{T}_{1}=100 \%$ whole wheat flour biscuit; $\mathrm{T}_{2}=75 \%$ whole wheat, $25 \%$ acha and $0 \%$ kidney bean flours blend biscuit; $\mathrm{T}_{3}=75 \%$ whole wheat, $0 \%$ acha, and $25 \%$ kidney beans flours blend biscuit; $\mathrm{T}_{4}=50 \%$ whole wheat, $25 \%$ acha and $25 \%$ kidney bean flours blend biscuit.

Calcium content in the biscuits ranged from 36.14 to $45.72 \mathrm{mg} / 100 \mathrm{~g}$ with sample $\mathrm{T}_{1}$ having the least value while sample $\mathrm{T}_{4}$ had the highest value. Biscuits from the composite flours that contained kidney bean flour $\left(\mathrm{T}_{3}\right.$ and $\left.\mathrm{T}_{4}\right)$ exhibited higher calcium content than those with on kidney bean flour incorporation $\left(\mathrm{T}_{1}\right.$ and $\left.\mathrm{T}_{2}\right)$. Souci et al. [48] noted that red kidney beans are the best source of essential minerals including calcium, potassium, magnesium, phosphorus and iron. Calcium plays important role in blood clotting, muscle contraction, and in certain enzymes in metabolic processes [49].

The magnesium content in the biscuits ranged from 29.60 to $46.8 / \mathrm{mg} / 100 \mathrm{~g}$ with the control biscuit $\left(\mathrm{T}_{1}\right)$ having the lowest value while sample $\mathrm{T}_{3}$ had the highest value. The values for magnesium in the biscuits were significantly $(\mathrm{p}<0.05)$ different from each other. Magnesium is important for bone health; is needed as a cofactor for numerous reactions in the body and is also essential for nerve and muscle conductivity [50]. High amount of magnesium, potassium and calcium have been reported to reduce blood pressure in humans [51].

The iron content in the biscuits ranged from 3.89 to $5.12 \mathrm{mg} / 100 \mathrm{~g}$. The lowest value was for sample $\mathrm{T}_{2}$ while the highest value was for sample $\mathrm{T}_{3}$. Biscuits that contained red kidney bean flour $\left(\mathrm{T}_{3}\right.$ and $\left.\mathrm{T}_{4}\right)$ had significantly higher iron content than the control sample $\left(\mathrm{T}_{0}\right)$ and sample $\mathrm{T}_{2}$. Red kidney bean has been reported to be a good source of iron [48]. The zinc content in the biscuits ranged from 2.01 to $3.51 \mathrm{mg} / 100 \mathrm{~g}$. The control sample $\left(\mathrm{T}_{1}\right)$ had the highest value while the least value was for sample $\mathrm{T}_{2}$. Iron and zinc which are known to be limiting in the diet of infants and young children are critical micronutrients for growth, development, immunity and health of infants. Iron is needed for the formation of hemoglobin, the component of blood cell that carries oxygen in the blood stream throughout the body [50]. Adequate iron in the diet is essential to minimize the incidence of iron deficiency anemia, which is considered as the most common nutritional disorder worldwide [52].

\subsection{Sensory Evaluation of the Biscuits}

Sensory evaluation of any food item is an essential component of food product development as it is used to evaluate the acceptability or otherwise of the product. In the present study, mean scores of sensory attributes of the produced biscuits are presented in Table 6.

Table 6: $\quad$ Mean sensory scores for biscuits made from whole wheat flour supplemented with acha and kidney bean flours

\begin{tabular}{lcccc}
\hline \multirow{2}{*}{ Parameters } & \multicolumn{4}{c}{ Sample Codes } \\
\cline { 2 - 5 } & $\mathbf{T}_{\mathbf{1}}$ & $\mathbf{T}_{\mathbf{2}}$ & $\mathbf{T}_{\mathbf{3}}$ & $\mathbf{T}_{\mathbf{4}}$ \\
\hline Appearance & $7.15^{\mathrm{a}} \pm 0.20$ & $7.00^{\mathrm{a}} \pm 0.15$ & $7.45^{\mathrm{a}} \pm 0.17$ & $7.08^{\mathrm{a}} \pm 0.14$ \\
Taste & $6.45^{\mathrm{b}} \pm 0.14$ & $6.30^{\mathrm{b}} \pm 0.23$ & $7.00^{\mathrm{a}} \pm 0.14$ & $6.80^{\mathrm{a}} \pm 0.09$ \\
Texture & $6.40^{\mathrm{b}} \pm 0.15$ & $6.20^{\mathrm{b}} \pm 0.19$ & $7.51^{\mathrm{a}} \pm 0.21$ & $6.35^{\mathrm{b}} \pm 0.13$ \\
Crispiness & $5.75^{\mathrm{b}} \pm 0.30$ & $6.36^{\mathrm{a}} \pm 0.26$ & $6.50^{\mathrm{a}} \pm 0.30$ & $6.72^{\mathrm{a}} \pm 0.15$ \\
Overall acceptability & $6.90^{\mathrm{b}} \pm 0.19$ & $6.70^{\mathrm{b}} \pm 0.12$ & $7.25^{\mathrm{a}} \pm 0.15$ & $7.00^{\mathrm{a}} \pm 0.20$ \\
\hline
\end{tabular}

Means on the same row with different superscripts are significantly different at $\mathrm{p}<0.05$. $\mathrm{T}_{1}=100 \%$ whole wheat flour biscuit; $\mathrm{T}_{2}=75 \%$ whole wheat, $25 \%$ acha and $0 \%$ kidney bean flours blend biscuit; $\mathrm{T}_{3}=75 \%$ whole wheat, $0 \%$ acha, and $25 \%$ kidney beans flours blend biscuit; $\mathrm{T}_{4}=50 \%$ whole wheat, $25 \%$ acha and $25 \%$ kidney bean flours blend biscuit.

The result showed that the mean scores by the panelists for appearance, taste, texture, crispiness and overall acceptability varied among the samples. Appearance and taste are important sensory characteristics that affect the acceptability of any food product by the consumers. Mean score values for appearance ranged from 7.00 to 7.43 and were not significantly $(\mathrm{p}>0.05)$ difference from each other. The mean score values for taste ranged from $6.30\left(\mathrm{~T}_{2}\right)$ to $7.00\left(\mathrm{~T}_{3}\right)$. The taste score values for samples $T_{3}$ and $T_{4}$ were not significantly $(p>0.05)$ difference from each other but were significantly higher than the mean score values for samples $\mathrm{T}_{1}$ and $\mathrm{T}_{2}$. The scores for texture and crispiness of the biscuits ranged from $6.20\left(\mathrm{~T}_{4}\right)$ to $7.51\left(\mathrm{~T}_{3}\right)$ and $5.75\left(\mathrm{~T}_{1}\right)$ to $6.72\left(\mathrm{~T}_{4}\right)$ respectively. The texture of sample $\mathrm{T}_{3}$ was the most preferred 
as the mean score value (7.51) was significantly higher than the rest of the samples. The control sample $\left(\mathrm{T}_{1}\right)$ had the least mean score $(5.75)$ for crispiness and the value was significantly $(\mathrm{p}<0.05)$ lower than the rest of the samples. Scores for crispiness for samples $T_{2}, T_{3}$ and $T_{4}$ were however not significantly ( $p>0.05$ ) difference from each other. The mean score values for overall acceptability ranged from $6.70\left(\mathrm{~T}_{2}\right)$ to $7.25\left(\mathrm{~T}_{3}\right)$. This indicates that biscuits from all the formulations were acceptable as they received scores greater than 5 (neither like nor dislike). However, sample $\mathrm{T}_{3}$ with the highest score (7.25) was the most preferred sample in terms of overall acceptability while sample $\mathrm{T}_{2}$ with the score of 6.70 was the least preferred sample. Overall acceptability mean scores for samples $T_{3}$ and $T_{4}$ were not significantly $(p>0.05)$ difference from other.

\section{CONCLUSION}

The study has shown that acceptable biscuits of improved nutritional quality and high dietary fibre content could be produced from blends of whole wheat, acha and kidney bean flours. Production of biscuits from whole wheat flour supplemented with acha and kidney bean flours will help to reduce dependence on wheat flour thereby reducing wheat importation into the country. It will lead to increased utilization of acha and kidney bean and farmers will be encouraged to produce more and generate more income. The high protein content in kidney bean incorporated biscuits could be used to alleviate the problem of protein-energy malnutrition that is still common in most of our communities. Also, the high dietary fibre of the biscuits would provide some health benefits to the consumers.

\section{REFERENCES}

[1] Omeire, G. C., Umeji, O. I. and Obasi, N. E. Acceptability of noodles produced from blends of wheat, acha and soybean composite flours. Nigerian Food Journal, vol. 32, no. 1, pp. 31-37, 2014.

[2] Bakke, A. and Vickers, Z. Consumer liking of refined and whole wheat breads. Journal of Food Science and Technology, Vol. 72, pp. S473-S480, 2014.

[3] Sivasankar, B. Food processing and preservation. PHI Learning Private Limited, New Delhi, 2011.

[4] Kumar, P., Yadava, R. K., Gollen, B., Kumar, S., Verma, R. and Yadar, S. Nutritional contents and medicinal properties of wheat: A Review. Life Science and Medicine Research, vol. 22: pp. 1-10, 2011.

[5] Ragaee, S., Guzar, I., Abdel-Aal, E. S. M. and Seetharaman, K. Bioactive Components and antioxidants capacity of Ontario hard and soft wheat varieties. Canadian Journal of Plant Scance, vol. 92, pp. 19-30, 2012.

[6] Chukwu, O. and Abdul-Kadir, A. J. Proximate Chemical Composition of acha (Digitaria exilis and Digitaria iburua) grains. Journal of Food Technology, vol. 6, no. 5, pp. 214-216, 2008.

[7] Coda, R., Cagno, R. D., Edema, M. O., Nionelli, L., Gobbetti, M. Exploitation of acha (Digitaria exilis) and Iburu (Digitaria iburua) flours: Chemical characterization and their use for sourdough fermentation. Food Microbiology, vol. 27, pp. 1043-1050, 2010.

[8] Oburuoga, A. C. and Anyika, J. U. Nutrient and antinutrient composition of mungbean (Vigna radiate), acha (Digitaria exilis) and crayfish (Astacus fluviatilis) flours. Pakistan Journal of Nutrition, vol. 11, no. 9, pp. 743746, 2012.

[9] Sarwar, H. The importance of cereals (Peaceaci gamineae) nutrition in human health: A review. Journal of Cereals and Oilseeds, vol. 4, no. 3, pp. 32-35, 2013.

[10] Jideani, A. I. and Akingbala, J. O. Some physicochemical properties of acha (Digitaria exilis Stapf and Digitaria iburua Stapf) grains. Journal of Science of Food and Agriculture, vol. 63, pp. 369-374, 1993.

[11] Temple, V. J. and Bassa, J. D. Proximate Chemical Composition of acha (Digitaria exilis) grain. Journal of Science of Food and Agriculture, vol. 56, pp. 561-653, 1991.

[12] Ibrahim, H. M. and Saidu, B. Effect of processed acha (Digitaria exilis) grain on glycemic index of diabetes induced wistar rat model. Scholarly Journal of Biological Sciences, vol. 6, no. 3, pp. 89-93, 2017.

[13] Yasmin, A., Zeb, A., Khalil, A. W., Paracha, G. M., Khattak, A. B. Effect of processing on anti-nutritional factors of red kidney bean (Phaseolus valgaris) grains. Food Bioprocessing Technology, vol. 1, pp. 415-419, 2008.

[14] Anderson, J. W., Baird, P., Davis, R. H., Ferreri, S., Knudtson, M., Korayam, A., Waters, V. and Williams, C. L. Health benefits of dietary fibre. Nutrition Review, vol. 67, pp. 188-205, 2009.

[15] Barapama, Z. and Simard, R. E. Oligosaccharide, anti-nutritional factors and protein digestibility of dry beans as affected by processing. Journal of Food Science, vol. 59, pp. 833-838, 1994.

[16] Shimelis, E. A. and Rakshit, S. K. Effect of Processing on anti-nutrients and in vitro protein digestibility of kidney bean (Phaseolus vulgaris L.) varieties grown in East Africa. Food Chemistry, vol. 108, pp. 161-172, 2007.

[17] Khalil, M. Effect of soaking, germination, autoclaving and cooking on chemical and biological value of guar compared with faba bean. Nahrung Food, vol. 45, pp. 246-250, 2001.

[18] Nergiz, C. and Gokgoz, E. Effect of traditional cooking methods on some anti-nutrients and in vitro protein digestibility of dry bean varieties (Phaseolus vulgaris L.) grown in Turkey. International Journal of Food Science and Technology, vol. 42, pp. 868-873, 2007. 
[19] Ndife, J., Kida, F. and Fagbemi, S. Production and quality assessment of enriched cookies from whole wheat and full fat soya. European Journal of Food Science and Technology, vol. 2, no. 1, pp. 19-28, 2014.

[20] Olapade, A. A. and Aworh, O. C. Chemical and nutritional evaluation of extruded complementary foods from blends of fonio (Digitaria exilis stapf) and cowpea (Vigna unguiculata L. walp) flours. International Journal of Food and Nutrition Science, vol. 1, no. 3, pp. 4-8, 2012.

[21] Chaudhary, R. and Sharma, S. Conventional nutrients and antioxidants in red kidney beans (Phaseolus vulgaris): An explorative and product development endeavour. Annals. Food Science and Technology, vol. 14, no. 2, pp. 275-285, 2013.

[22] Man, S., Paucean, A. and Muste, S. Preparation and quality of gluten-free biscuit. Bull. UASVM Food Science and Technology, vol. 7, no. 1, pp. 39-41, 2014.

[23] Akubor, P. I. and Ukwuru, M. U. Functional properties and biscuit making potential of soybean and cassava flour blends. Plant Foods for Human Nutrition, vol. 58, pp. 1-12, 2004.

[24] AOAC, Official Methods of Analysis (18 ${ }^{\text {th }}$ edn.) Association of Official Analytical Chemists. Washington D.C., USA, 2005.

[25] Onwuka, G. I. Food analysis and instrumentation. Naphthali Prints, Lagos, Nigeria, p. 89, 2005.

[26] Osborne, D. R. and Voogt, P. The analysis of nutrients in foods. Academic Press, New York, p. $237,1978$.

[27] Ihekoronye, A. I. and Ngoddy, P. O. Integrated Food Science and Technology for the Tropics. MacMillan Edu. Publishers, London, pp. 172-193, 1985.

[28] Thongram, S., Tanwar, B., Chauhan, A. and Kumar, V. Physicochemical and organoleptic properties of cookies incorporated with legume flours. Cogent Food and Agriculture, https://doi.org/10.1080/23311932-2016-1172389.

[29] Gaines, C. S. Influence of chemical and physical modifications of soft wheat protein on sugar-snap cookie dough consistency, cookie size and hardness. Cereal Chemistry, vol. 67, pp. 73-77, 1990.

[30] Eissa, A., Hussein, A. S. and Mostafa, B. E. Rheological properties and quality evaluation of Egyptian balady bread and biscuits supplemented with flours of ungerminated and germinated legume seeds or mushroom. Polish Journal of food and Nutrition Science, vol. 57, no. 4, pp. 487-496, 2007.

[31] Zucco, F., Borsuk, Y. and Arntfield, S. D. Physical and nutritional evaluation of wheat cookies supplemented with pulse flour of different particle sizes. LWT - Food Science and Technology, vol. 44, no. 10, pp. 2070-2076, 2011.

[32] Tiwari, B. K., Brennan, C. S., Jaganmohan, R., Surabi, A and Alagusundaram, K. Utilization of pigeon pea (Cajanus cajan L.) by-product in biscuit manufacture. LWT - Food Science and Technology, vol. 44, no. 6, pp. 1533-1537, 2011.

[33] Kohajdova, Z., Karovicova, J. and Magala, M. Rheological and qualitative characteristics of pea flour incorporated cracker biscuits. Croatian Journal of Food Science and Technology, vol. 5, no. 1, pp. 11-17, 2013.

[34] Khan, M. A., Akhtar, N., Ihsan, U. and Jaffery, S. Nutritional evaluation of desi and kabuli chickpea and their products commonly consumed in Pakistan. International Journal of Food Science and Nutrition, vol. 46, pp. 215 223, 1995.

[35] Hayat, I., Ahmad, A., Khalil, S. and Gulfraz, M. Exploring the potential of red kidney bean (Phaseolus vulgaris L.) to develop protein based product for food applications. The Journal of Animal and Plant Sciences, vol. 24, no. 3, pp. 860-868, 2014.

[36] Awan, J. A., Rehinan, A., Rehinan, S., Siddique, M. I. and Hashmi, A. S. Evaluation of biscuits prepared from composite flour containing mothbean flour. Pakistan Journal of Agricultural Science, vol. 32, no. 1, pp. 211-217, 1995.

[37] Tharanathan, R. N. and Mahadevamma, S. A review: Grain legume a boon to human nutrition. Trends in Food Science and Technology, vol. 14, pp. 507-518, 2003.

[38] Igbabul, B. D., Iorliam, B. M. and Umana, E. N. Physicochemical and sensory properties of cookies produced from composite flours of wheat, cocoyam and African yam beans, Journal of Food Research, vol. 4, no. 2, pp. 150-158, 2015.

[39] Ikuomola, D. S., Otutu, O. L. and Oluniran, D. D. Quality assessment of cookies produced from wheat flour and malted barley (Hordeum vulgare) bran blend. Cogent Food and Agriculture https://doi.org/10/1080/23311932.2017.1293471.

[40] Peter, I. A., Okafor, D. C., Kabuo, N. O., Ibeabuchi, J. C., Odimegwu, E. N. Alagbaoso, S. O., Njideka, N. E. and Mbah, R. N. Production and evaluation of cookies from whole wheat and date palm fruit pulp as sugar substitute. International Journal of Advancement in Engineering Technology Management and Applied Science, vol. 4, no. 4, pp. 1-31, 2017.

[41] Ajibola, C. F., Oyerinde, V. O. and Adeniyan, O. S. Physicochemical and antioxidant properties of whole-wheat biscuit incorporated with moringa oleifera leaves and cocoa powder. Journal of Scientific Research and Reports, vol. 7, no. 3, pp. 195-206, 2015.

[42] Satinder, K., Sativa, S. and Nogi, H. P. S. Functional properties and antinutritional factors in cereal bran. Asian Journal of Food and Agro-Industry, vol. 4, pp. 122-131, 2011.

[43] Slavin, J. L. Dietary fibre and body weight. Nutrition Journal, vol. 21, pp. 411-418, 2005. 
[44] Weickert, M. O. and Pfeiffer, A. F. Metabolic effect of dietary fibre consumption and prevention of diabetes. The Journal of Nutrition, vol. 138, no. 3, pp. 439-442, 2008.

[45] Farzana, T. and Mohajan, S. Effect of incorporation of soy flour to wheat flour on nutritional and sensory quality of biscuit fortified with mushroom. Food Science and Nutrition, vol. 3, no. 5, pp. 363-369.

[46] Adrogue, M. D. and Madias, N. E. Sodium and potassium in the pathogenesis of hypertension. New England Journal of medicine, vol. 356, pp. 1966-1978, 2007.

[47] Liu, D. T., Wang, M. X., Kincaid-Smith P. and Whitworth, J. A. The effect of dietary potassium on vascular and glomerular lesions in hypertensive rats. Experimental hypertension, vol. 16, pp. 391-414, 1994.

[48] Souci, S. W., Fachmann, W. and Kraut, H. Food composition and nutrition table. Medpharm Scientific Publishers, Stuttgart, 2000.

[49] Abulude, F. O., Lawal, L. O., Ehikhamen, G., Adesanya, W. O. and Ashafa, S. I. Chemical composition and functional properties of some prawns from coastal area of Ondo State, Nigeria. Electronic Journal of Environment, Agriculture and Food Chemistry, vol. 5, no. 1, pp. 1235-1240, 2006.

[50] Grosvernor, M. B. and Smolin, L. A. Nutrition: From science to life. Harcourt College Publishers, New York, pp. 404-469, 2002.

[51] Ranhotra, G. S., Gelroroth, J. A., Leinen, S. O., Vrnas, M. A. and Lorenz, K. J. Nutritional profile of some edible plants from Mexico. Journal of Food Composition and Analysis, vol. 11, pp. 298-304, 1998.

[52] Short, M. W. and Domagalski, J. E. Iron deficiency anemia: Evaluation and management. American Family Physician, vol. 87, no. 2, pp. 98-104, 2013. 